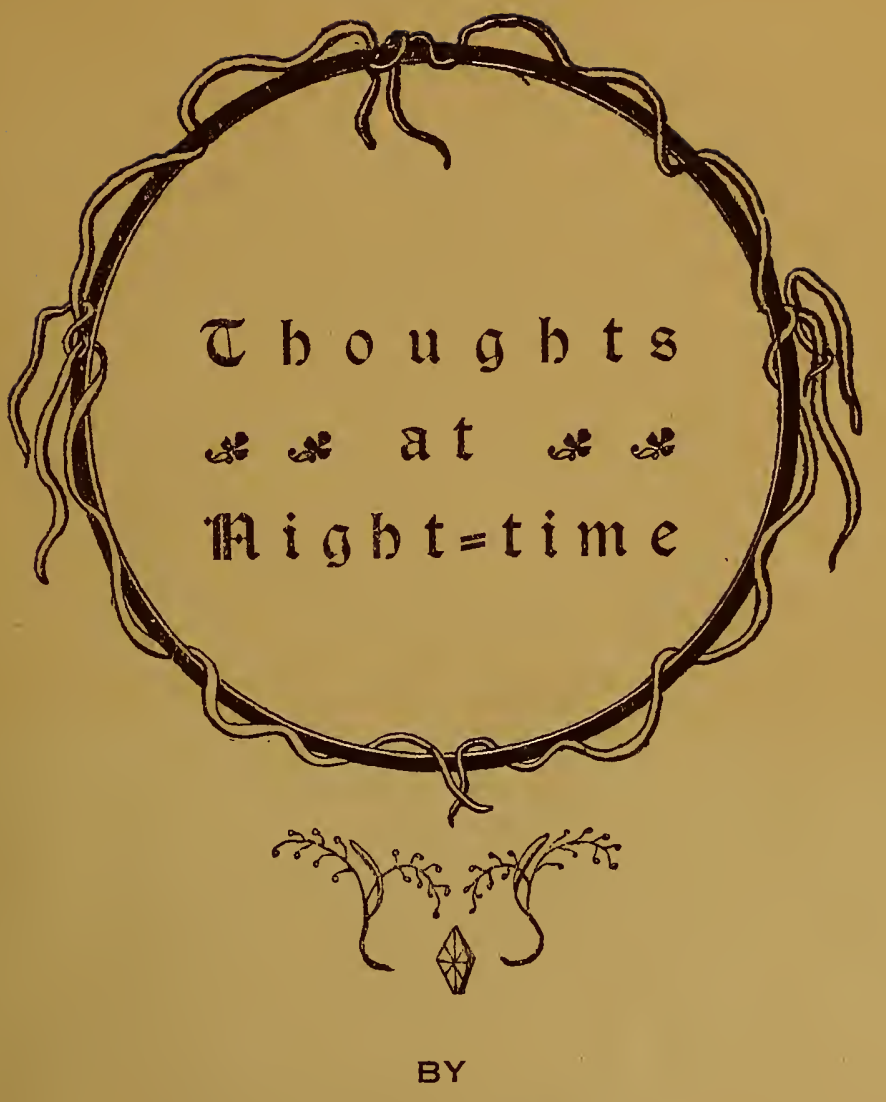

LOUIS M. ELSHEMUS

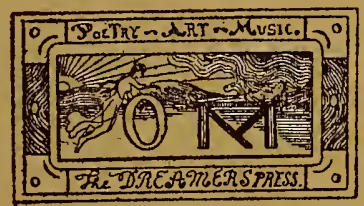

The Dreamerg Dress

132 East 23 ro street Room 1

Thew Work

$152 T 5$ 



\section{Choughtsat Thight=tíme}

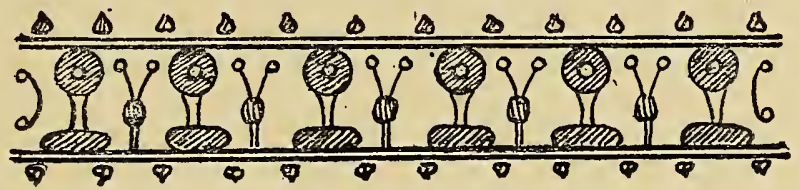

BY

\section{LouIS M. ELSHEMUS}

Futhor of "Fbout Girlig;" "MDoods of a Foul;" Etc.
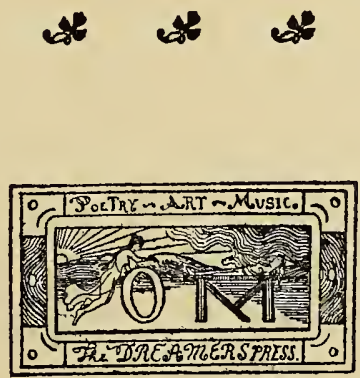

The Dreamers $\mathbb{p r e s g}$

132 East 23ro gtreet

Room 1

T2ew Work 
COPYRIGHTED 1909

BY LOUIS M. ELSHEMUS 


\section{Thoughts at Mighttime}

\section{1}

'Tis grisly night calls out the dreary hour!

Now thought, like to the hooting owl, wings bold

The uncertain eboness of Nox's air-

And flutters brokenly through gloom and pitch

Of the vast realm of thought long dead: Oh! thought,

The numbered sages, ancient as hoary Time,

In ignorant, egotistic pride had uttered!-

For is it not grim pride that ekes a thought

A thought we think our own-when lo, two scores

Of æons far away in infinity

Some other dreamed of it in same-fold, triumphant

Importance! Oh! thoughts, what are ye to us men?

The ripple on the Amazonian currents furious -

The down upon the cheek of Sappho radiant-

The moat that fills the sun-ensilvered air-

The whisper of a Sophocles inspired-

The leaf-vein of the mighty Boabab frutescent-

The laughter of our ponderous globe, levin-circling.

So are our thoughts! Who made them so important?

For have not ages shown that wondrous thoughts

Of ages gone are now but child's mere play?

Columbus bristled with triumph when he sailed

With shell-ships o'er the unknown ocean's bound-

He thought it marvelous. But now we dash

Across the same wild tempest-ravaged main

With one colossal ship in four days' time-

When he took months to cover three thousand miles!

Oh! thoughts we now may deem important, may

In thousand years seem but a lad's delight.

For, who doth know? then might the realm of air

Be conquered-lo, I say not what might be!

So thought $I$, as the night her shafts of frost

Hung on the earth, in ermine robes enshrouded-

And like a brittle bowl lit by the sun,

Shoots forth swift rays of light intensest known,

So sparkled the stars, far in the blue inane!

\section{III}

Now from the North Pole growl the icy galesThe North Pole, unexplored by any mortal - 
Locked-uninhabited-for lo!-the Marvel, Almighty Wonder, that invades our souls Hath from Beginning's Hour made that check, so man's Presumptuous, curious, overbearing ego Should cringe at times, and cower, snarling Like curs, fletching their tongues, to semble Obedience; aye-gaze upon intrepid Explorers who, in spite of seeing harsh death Their rash endeavors frustrating, yet will set Fierce sails on toy-like barques, and sail Up to that iceberg gloom profound-when lo! Either they must return, or what most haps, The North Pole's icy circle checks their onslaught; Their skeleton, the only vestige of their daring, Lying there, grimmest warning to some follower. Now from the North Pole howl the icy gales; All suffer-in feeling of the neighborly sea. But, oh! what cold reigns in the mountains far, Some hundred miles away! I, too, had known Such cold intense, when youth was still my ward; And as I dream, now comes to me the time When after only an hour's walk o'er snow, In air ice-cold, I felt the chill make stark me; Aye, I was frozen- I felt falling asleep;

Then, as I entered a lone cottage hallMy saviour; I fell aground, impotent, foam Slow flowing from my mouth-ay, I was frozen! Saved by the cottage, where the people came And gave me warmth. Such was my fate to live yet. And here this day, many a man and matron Succumb to this intense clear boreal air; The poor child dying in its mother's armsThe barefoot urchin freezing at some cornerAnd, oh! some outcast maiden, huddling close To dark despair, daed, on the cindered snow! And here I pen these thoughts, in sumptuous room, With gay lights, and my many paintings round meRight royally I'm housed; oh! can I grumble? However, my star compels my grouchy mood. Oh, we poor puppets of the influencing planets! While here I am alone, with thoughts surrounded, I bethink me of the thought of all the dead onesFar back to King, to Solomon, to RahThose million thinkers thro' the ages buried. Thought that we still in tones may vibrant find Undying! What assiduous hours-aye, yearsThey spent to solve the strange, weird mysteries- 
Those intricate broodings that in our soul arise Like from a clear sky shapeful summer clouds; Those all-insolvable visions streaming to us. There's nought in nature's embodied pageantry That can compare with those that, all unseen To the body's eye, yet are so palpable there Before our mind's so mystic orb unknown. Those visions but the perfect poets perceiveOr prophets, they of Moses' day by Horeb hoar! I dream of them; those seekers aft' the TruthMeek Jesu; noble-souled Buddha; Luther; Sad Leopardi; Dante; Rousseau; much-maligned Manzini; Whitman; all those fiery spirits, Outshining millions of mortals; what had they To do here for the world? What madness manacled Their minds to melodise rapt strains, illumined, For their low fellow-beings, chained to aperyDoomed to live a humdrum year, innescient Of all the beauties permeating artist souls, Then vanish from the earth as in the murk Fog-night; a will-o'-wisp o'er a marrish dank! What toil it was, as with sweet Rousseau's craze To enlighten those with no capacious brains To harbor all the wisdom, loftiness of his soulVain, vain-new generations will evolve, And like the rubious fire-flower that beautifies The ground where conflagration's ruins lie, So bud and bloom new minds that aye forget The glory-trumpets that their precedents had blown! $\mathrm{Me}$, too, in youth's most golden glory-days, Great Rousseau's stern "Reveillé" held me bound. Methought to live as he-but then what hovered Around my joyousness to be his echo; I saw my fellow students leading lives So far remote from that philosopher That like to some archangel visioned of Job, Sad at the truth that mankind in assemblage Is not what is a noble individual, I slunk to my retreat, and there worked out My own salvation; feeling what a vain And unrewarded task it is to preach high aims; For as I saw that most preferred warm pleasureMost sought to ape the masses--to revel in playWhat booted it to actuate such crowds to soar To regions where a spirit beauty day shone fair? Aye! Rousseau wrote grand morals - of his times The greatest scribe; yet now, aft' hundred years, 
Who knows him? Guffaws greet him; in our land Not one has read his works; such towering wisdom!

I also, awed by nature's opulent creations,

Was wont to wield the bands of fair reform;

And like a Shelley's, rapt fire exordiums

Scintillated; who in all the world has conned

Their ennobling strains, their rapture eulogiums

To the Creator? comes the thought to me,

While night advances and the air grows colder.

It seems the great in soul must sing their song,

Though unrevered by all the multitude;

It is perchance our fair apprenticeship

That thus we curse and rage at worldly life,

And thunder at the tyranny of cruel men,

Denounce the governments that live on spoils,

Exhort the heads of nations, pray for the poor-

Who knows? Oh! well it is - tho' no one lives

Up to the precepts of the philosophers,

Nor educates a nation so love should reign.

I know we sad, sweet singers, serene of soul,

Tho' all the world begrimes our life with scorn-

We sang for ye who knew it not-but lo!

In Aiden, rare fresh land, there we shall go,

And never there be, as we're here, forlorn!

\section{\III}

This evening, at the dusky hour, Hesper shone

As tho' a pale, huge opal flashed by the sun-

A range of light blue cloud, baft of the town,

Seemed like some arrass-shoud, hung 'gainst the pink

Bare wall of Mufti's sacred temple-chamber.

The western sky above this cloud gleamed rosy,

Melting to gray, lit by some recreant rays

Of the long-dead sun; above this faint, strange glare

Slowly there breathed a filmy, purplish hue,

That slowly deepened higher up to one

Wide, doming, bluish-purple, spreading weird

Around, above-that was the veil of night!

And in that veil, like to a sparkle of joy

That emparadises the violet orbs of Lillian,

The beautiful maid of Erin-in that veil

Fair scintillated the diamond eevning star!

Such was the evening. But now, what change!

The wind from north, cold blowing, has abated-

The east gale now invades the winter rude,

Sweet-tempering the frosty air. The sky,

So fair and purple, clear and star-bestrewn, 
Is now all clouded; fogs from the near banks,

Warm breaths that wander from the far gulf stream,

Flow grateful to the shores, where long the ice

And cutting winds their menace wrought on fold

And shivering populace. And now I hear, far out,

Where ice-floes cumber the wide, swift Hudson's flow,

Weird foghorns sounding, some like bellows faint,

Of kine lost in some mountain close forlorn;

Some like the distant rumble of a terror-train;

Some clearer, like the shriek of maiden, hid

In some drear forest-cave; then two sounds now-

Then three sad moans-then more, in unison-

Then east wind, tho' thy blowing melts the snow,

Thy cloud-evolving breath works havoc to our own:

Skiffs, crafts, steam, sail, all sightless in thy shroud,

Pending some sudden, shudder-filling doom!

Such a sad night portends no good; yet hail!

East wind! thy breath has melted winter's heart-

To-morrow bland will blow thy sea-drenched wind;

The snow must vanish, and soon-aye, soon-thou wilt

Be kissed to death when the south wind comes rollicking

To pledge himself fond friend of the warm sun.

"Tis night; methinks of all the motley men

That aggregate this strange humanity-

Pride-lost-greed-chained. What thoughts invade the minds

Of those who never claimed calm reverie's smile,

Nor sought the sweet seclusion of deep thought!

Those who ne'er fathomed all the secret sounds

That high Beethoven heard within his soul-

Those never learning how to mix rare colors

To paint a picture wrought by da Vinci's vision,

Or study the human frame to sculpt fair statues

Like Buamarotti or sweet Canovà.

What thoughts leave they beside trade, artifice,

The struggle for existence, of their body's pleasures?

How can they love to listen to melodious works

Of Chopin, Field, or him who brought down Heaven:

Mozart ethereal? How can they gaze on paintings

Such as Rousseau, Corot wrought, with fancy conceived?

How can they tread a "Festus" or Milton's epic wondrous?

Impossible! Where is their world on high?

Where is our world-we who from infancy

Have sung, drawn pictures, wrote full well?

Oh! mystery beyond mystery! Some say

Our life is an apprenticeship-when lo!

A prodigy-a genius-youth creates

More perfect works than he who worked a life-time. 
Unsolvable riddle-this our being hereWe glorious ones, in midst of ignoranceLike eglantine aglow-amid marsh-weedsWhy do we give sweet birth to transcendent thoughts, When none of the multitude can compass them?

Riddles, aye, riddles never to be known!

Then work away-each labor at his task-

At death we'll know the truth. So thought I, lone Conversing with the dark depths of the night.

Feb. 10, 1908.

\section{0}

Oh, night! thou solemn solacer of the student;

When turmoils of the day are over, sweet

Resounds the curfew; sweeter sounds the calm

IVithin the room; that calm, promoting thoughtInducing philosophic dreams to rise;

As o'er an evening mountain-crest pink clouds,

Slow-wafted by a southern breeze, ascend

The skies, irradiant in the afterglow!

Sweet consolation, calling, where defeat

Held us in bonds. Oh, night! I now salute thee.

How oft', in chilhood's hours, I sought thy balm,

When boyhood wove around my mind dream-webs!

How often to my mansard I repaired,

Away from motley parley, common banter,

To find thee, waiting me-and there we dreamed!

How many a solemn chant I built for thee,

With arms extended to thy fathomless realm

I supplicatingly gazed at thy fair stars,

Thy weary moon, and vowed to live thy thrall!

Now think I of the countless eyes that gazed

At thee, and all thy magic mysteries

Through thousand ages. Men of famed Cathay

Have studied thee-before the Biblic Flood-

Pre-Christian Arabs lay upon the desert

Thy stars to count; and from their fixèd figures

Evolved hard sciences for us to learn.

Then, in these modern days, great men still pore

O'er thy blue heights, and bottomless depths, to seek

New wonders there: the icy air, above

The aura of this ponderous globe of ours-

Where silence, black as jet, holds sovereign reignBut no one, furnished with his telescope,

May tcll what rules the terror-speeding spheres,

What laws, if any, do bid the planets roll 
Thro' orbits fore-ordained ere chaos waned!

What magic machinery, invisible to man

(Mayhap all framed with lightning's quivering stuff!)

Makes move the trillion globes, we see from here

As stars, fixed, or in wondrous whirl, heaven-voyaging!

Much have they learned from lone descrying

Thy vastness, thy charm, of aurate stars, or those

That flame pink, green, lazul or diamond-white-

Much seen of sun, planets and constellations-

The heaven's secrets deep, stili lie deep hidden-

The elements, the airs, the sightless paths-

All these and more thon keepest locked fore'er.

Alone to thee, thou awful night, they are divulged;

Thou reignest in the vastness, all superior, still!

So thought I, as on thee I cast stern glances,

Wishing thee to understand; but lo! thou art

A wonder - not a man with superior soul

May fathom thee. Then drean-envelop this earth;

A breath of the black silence in thy depths

Fond flow to shroud this world, where most are fain

To wrest one more deep secret from thy realm;

But like the feathery foam from the loud surge,

Upbearing its weightless body aloft the lea,

Then vanishes, lost forever to this sounding sea-

So dost thou show for man some secret sparse,

Which he beholds, but would he delve it-lo!

Sightless to him it resolves to darkness deep.

Feb. 2, Igo8.

ט

Implacable night!! what prayers we say to thee-

With not one answer. Reign thou, stubborn, proud;

Thy glory might be only semblance strange

Of thy supernal power. What waileth far oh! far,

Beyond thy scintillating stars; beyond the thread

Of silvern patins, eternal waving in thy realm-

What canst thou answer, thou voiceless one?

Oh, elements! what are ye? Not as dumb as we

Think that you are. Oh! might we learn your tongue,

Perchance our woes would find an end; and joy

Would settle lasting in our sad world's bosom.

Avaunt! thoughts, eager to explore the inane,

As some skiff, sailing on the sea, we see it

From where we stand on heather-strewèd cliffs;

We follow its course as to the ocean's rim

It glideth, gradual, fading till it melts- 
Then from the ocean's marge it vanishes-

So seems a thought, weird-given to secrets dark,

That might be sealed within thy vast, deep space.

We poor, inquiring mortals see them loom

Upon our mind's strange main-but soon, too soon,

They die beyond our mind's horizon-far-

To never rise again. Full oft my thoughts

Have wished to delve thy bluey depths-full oft

They wished to seek some light so recondite-

Unknown to the astronomer's bounded lore.

Oh! wrench from thee some truth; but vain was all.

I questioned thee-mute, inconsolable

Thy majestic, matchless sternness kept aloof ;

And now I've let my thoughts re-wander far

Into the void of thee, night! Vain, oh, vain!

So must it be that the Almighty placed

Thy splendors, and the marvel-moon and stars,

Around our earth, that we should laud His might, And kneel in awe before His inscrutable powers!

Feb. 15, 1908.

\section{טI}

Vapors all morning - a circle of blue at noon;

At evening, rain-and now, still rain and fog!

'Tis dull to-night-no stars, no sky serene.

Ay, now I hear the first shower of this year!

Soft had it come, then like a seething

The rain poured down-ah, me! for but a moment.

Then hear I one soft drop against the pane-

Now utter stilness-only clanking faint

From trolleys; then the clatter of a cart

With hoof-clacks intersounding. Again the rain-

Of sudden-short-then dying with a sighing,

As on the Cretan Sea the breeze at eve!

Again, as surf when lovers hear it soft,

They lying in a dune, with glories, white and pink,

Sweet-spotting it; then the trickle of slow drops

I hear-as tho' a sweet four-year were tapping

Against my studio door. Then quiet-and night

Lies hushed. This is the first fair shower seeming

Like Springtide's, when sweet May is blooming, dreaming!

That comes here, while as yet 'tis Winter drear!

Now waft my thoughts, as halcyons o'er the main,

When tropic stilness halts the creamy clouds,

And makes of all the air one hymn, uplifted

To God the Lord! Thoughts, not all new to men- 
Yet thoughts men might know, but keep secret there Within their hypocritic brains. While passing A playhouse-large likenesses of beauty-mimes Shone radiant in glass casements for displayLanguid her pose-rich-garmented, as tho'

She were some queen, of noted men adored; Then others, in scant garb, her shape aglow, Her smiling lips, her scintillating eyes

Revealing thoughts libidinous and free.

Such viewed I; then most solemn pictures glowed

Within my dreaming mind. Oh! world-is beauty

The portal to a temple to passion dedicate-

Is beauty but a snare that nature wrought

To lure us potent men to lust, "amouring"?

Has beauty nought of sanctity that love induesCan Art not claim a right to her beautyship?

And Music, from whose wells rapt beauty risesCan she not own a beauty to inspire her songs?

And Poesy, she who makes rare beauty's charm

Her load-star, sings of her from year to year-

Can she no rare, volputuous beauty find

Who will sweet loll in loveliness for her?

But nay! Art, Music, Poetry, live, shorn

Of beauty's sweet companionship; what beauty

Will be for once, fair company to those

Who sing, create rare symphonies, and paint

Most exquisite? To panders, beauties fall

Low victims; to lust, rare beauties pledge their lives;

To passion they bow cringing; where's the glory

Of beauty's reign? Where shines her sacredness?

Where is her star, that should illume Love's heaven?

Not thou, impenetrable night, with all thy weirds,

Like Endors, prophesying silently-

Not thou, in whose vast depths lie spirit-soothes,

Canst utter causes strange of beauty's fate:

Tho' dowered with love, she is a thrall to lust!

Gaze thou along the laurelled avenue

Where fame hath niched the worthies of all time-

Who of the myriad illustrious artist-heads

Has owned a beauty, instilling in their lives,

So woe-forlorn, rapt glow-creations-such,

If wrought, would have outshone the fairest epic

The muses ever gave. Where are they? Vain

Is all our searching; genius knows no year

That hath enwrapt him with a beauty's love!

But glance adown the grim history's blood-stained roadAnd there, engarlanded, with hyacinth and rose, 
At the feet of glorious kings, and conquerors bold, Lie, languorous, famed beauties, famed for charms That but the carnal appetites enchain-but where Is one who for her mind's fair attributes Was chosen as favorite? None-none! Go thou To Alexandria, or fair Misenum, And ask some poet what he knows of beautyWhile gazing at the Nilus, serpenting Thro' level hands of foison, sun-besparkled, He'll tell the tale of her who swayed all menShe was a beauty-but her life gave tribute To Belus gay. Ere Antony swore love

To her, she was a glee-girl - a prostrate slave

To richest potentates-exhausted coffers

Of young gallants-and reigned, supreme, unchecked, The queen of harlots, thralls of Aslitoreth!

Oh! countless beauties, history-chronicled,

Have shown themselves mere passive toys of those

Who look at loveliness but for pleasure's sake.

Thus Messalina-Antoinette-a thousand others.

Yet, waive hard commendation, beauty-night-

Not all their fault-they also feel sad woe-

For doth not beauty rash incite our passion?

Virginia, sad, sweet beauty, tender-yeared,

Was victim of base Appius Claudius-not

Their fault, oh, night!'twas nature made us menShe made rare beauty for his passion-moods.

So, peace! No change will be, till earth vanishes.

Feb. I4, 1908.

\section{WIII}

Interminable alternation in thy ways,

Thou night! 'Twas yester-eve that fog lay thick

Beneath thy radiant realm, to us enveiled-

Fog, like a wall impenetrable, sightless to make

Thy wonder-regions in the infinite!

And now, one windy, shivery day of sun between,

Thou holdest glorious festals, while crystal-clear

Thy vastness quivers above this earth of ours,

Thy golden stars, or diamond-white, or red

As rubies, flashed by incandescent rays-

Or green as are the sides of breaking waves,

Thy myriad various-colored stars shine high,

All palpitant, like flower-fields at morn

Bedewed, bright-laughing, or twinkling a-sunAll hymning, a-chorus, triumphantly to God! 
Then glow new thoughts within my wondering mind;

Long have I sat on the verbena-broidered lea,

That hears the ocean vast of dreams and thought

So fair, as by far Montecito's flower-fragrant shore:

In view of the Pacific, calm for evermore,

There sat I, and strange truths came there to head.

$\mathrm{Ah}$, me! discrepant are the views of men

On topics of this world. One deems it wrong

To sing of sensuous sweetness-passion's bliss-

While some love loveliness, a sweet girl's kiss.

One thinks it gross to linger in dreams a-glowing

Of Dian's voluptuousness, her limbs' fair flowing;

While others celebrate rare woman's charms

And dote on all that gleeful passion warms.

Aye, who is right? Should Bion lose his laurels

Because he was no saint, like Herbert, hymning-

Should Wordsworth be revered for nature-limning-

Yet had no sense to sing of virgin's sweetness?

$\mathrm{Ah}, \mathrm{me}$ ! what cares our God for senseless quarrels?

He made all fair; all's right for singing's meetness!

Then vaster thoughts rose in my mind, as clouds

That cluster round fair Aetna's snow-capped crest-

How can the songs of greatest poet be known

To worldly brains-how can a giant epic

Be understood by those who ne'er read poems:

Those who know nought of Aschylus or Buddh?

Then seems the verdict of the world so trite-

The same as when a Milton seeks to mate

His knowledge with the sapiency of a Seraph-

Or some proud scientist, proclaiming truths,

Discovëries, when aeons ago it was

A plaything in the spirit of eternal power!

Yet, in this world of ours, most seem to find

Fault with those things of which they nothing know-

Forgetting that long years of study must pass

Before their brains may seize the higher lore!

Yet peace! The world does not improve-narrow

Its mind has been, will be. So let my thoughts

Be like to thine, O Night!-vast, endless fair,

All-encompassing-praising everything!

Feb. I7, I908.

\section{VTHTII}

Again a change-thro' days the swirling snows

Ran riot thro' the east-wind-fretted airs;

At eve it rained-and now the skies are gray, 
While temperate gales send respite to the poor.

Now, in my lonesome art-retreat, I ponder-

O Night! - no thought to tender thee upshines-

No thought comes to my mind-then blooms at once.

A thought of how a thought glows in my soul:

Unwitting-unpremeditated-sudden-

When now, altho' I think, no thought looms up-

But as is thy gray sky, so is my mind!

Then night, whence came those former thoughts

I furbished with fair words so grandly well?

Where is my thinking-power? Ay, do we think?

Or are we sweet possessed of spirits rare

That give us thoughts? For surely, tho' I try

Assiduously to find a thought to sing upon-

The only thought I see is to think of thought!

Feb. I9, I908.

푸

Last night I was so sleepy, thought-bereft,

That to our secret sessions, Wonder-Night,

I could not wander. Oh! is man's strong mind

Thus stern enslaved by powers, none may rule?

Was I enfeebled, or was my brain at fault?

My spirit worked, but, ah! my brain was tired,

And needed rest. So sped I fast to where

Morpheus muses by the superworldly marge

Of dreamland-far in regions, round fair Heaven!

To-night my brain works with my quickened spirit,

So can my hand quide thought and pen to sweet

Converse with thee! I gaze Orion shines.

With all his ponderous, resplendent maejsty-

Ascending from the south the clear blue zenith-

Oh! what a whirl of thoughts, while viewing all

The stars, scattered-then rivet one's awe-thrilled glance

Upon yon constellation-age on age.

The same in shape, in number of its stars,

Its orbit, steadfast to th' impellent force

That, aens ago, had hurled it far in space-

Oh, infinite! No moon plains o'er the floor

Of thy fair realm-yet there is light-no darkness

Such as we are wont to call thee, Night-

Dark, black Night! Why? Nay, light intense-

And lambent light, light that scintillates-

Oh, Night!-mankind hath slandered thee-to call

Thee dark, and dreary-dread, uncanny-

Where is thy darkness, when no vapors veil 
Thy airy floor, that hides thy stars the while?

Where is thy dreariness, when all thy orbs

Dance living rays-the Pleiades show forth

Their dazzling bevy of spheres, in company?

Where is thy dread, when on the earth soft light

Makes beautiful the scene, and in the vale

Sufficient light suffuses so sweet love

May see his eyes? Why call thee uncanny, when,

If fear we feel, we turn our glance to thee,

Where thy irradiant stars ring glory to our qualms?

So, Night, I sing to thee in novel strains:

Sweet light thou sheddest on our earth that dreams

Unknowing what thy splendors and thy deeps

May to some questioning mortal mean! Light! light!

The sun, thro' day, with edge-blinding rays illumes,

Supremely bright, our small earth-orb; at eve

He flees from us, we thinking with his death

Light should be gone; but, lo! when thou in dusk

Preparest us with dread suspicions that light

Be utterly extinguished, and when it darkens,

Lo! sparkles not unheralded Hesperus-

He herald to all the slow, oncoming hosts

Of brilliant orbs, that seem to swing ecstatic

As to a morriss-measure, or seem to rejoice,

With resonant Hosannah-antiphonies

Enmusicking thy reign! Yea, thou, O Night!

Hast radiant glows within thy vasty space;

Not dark art thou-our earth is dark-but lo!

We look skyward, and countless corruscant lights

Shed, congregate, in figures assemble to show

That thou, Night, art with living spheres aglow!

[Here I had to discontinue, as I felt a sudden pain in my brain.]

\section{NIGHT THOUGHTS TERMINATED.}

\section{(WRITTEN AT DAYLIGHT.)}

When last I sat me on thy perilous heights,

O fathomless Night! to try to delve alone

With thought and spirit-flame thy secresies-

My mortal brain felt sudden a strange sense

That seemed as tho' some demon's hand pressed hard

Upon its convulutions; too deep my thoughts

Had penetrated in thy weird domain-

That indisputably hath bournes set round it-

Whose repellant substance doth forbid man's entrance.

So was I forced to cease my inquiries- 
Forced with thy matchless might to end discussionBrain-lamed, my soul fell prostrate, shorn of powerLike Icharus, who, bold, winged toward hunge Sol, Thinking to outclipse his blinding light, when lo! $\mathrm{He}$, too, wing-lamed, was hurled to earth-so I, Who dared too much; for bounded are man's thoughts; eYa, bounded with an iron wall, whoso will soar Above, must straightway fall : maimed, blinded, impotent! So will I no more seek nocturnal hoursNo longer query thee-nor try to know What hidden glories dwell back of thy veilFor well I think now: we children of the night Must be content to love as He thought wellMust study what with our eye we may see; But woe to him who, imagiration-thrilledWith too-inquisitive, rash a voice, demands Knowledge that only Hierarchs, Heaven's lords, Are allowed to harbor in their spirits clear! Oh, Night! farewell! No more thy mystic might I shall importune. 'Tis well, 'tis well! To adore Thy marvel-moon-thy countless stars-the blue Of thy uncircled dome and concave floor'Twill be my pure delight, when walking lone On earth-meditating glories soon to come!

Feb. 25, 1908.

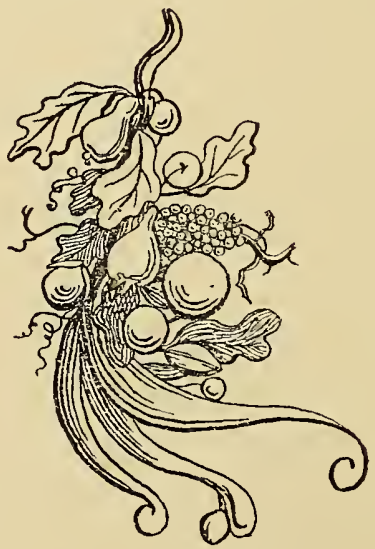


SMITHSONIAN INSTITUTION LIBRARIES

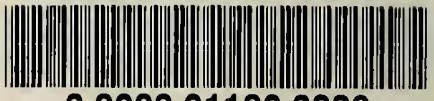

39088011903226 